\title{
Chromium in controlling diabetes and metabolic aspects
}

\begin{abstract}
Chromium can be found chemically in different forms among which trivalent form is beneficial and hexavalent is toxic. Chromium has various benefits in acting as antioxidant agent. It has been widely studied in metabolic diseases. Chromium was found to help in improving the function of insulin and accordingly it can be used in controlling type 2 diabetes. As a conclusion, chromium supplementation should be considered in controlling diabetes and other metabolic diseases.
\end{abstract}

Keywords: chromium, trivalent chrome, hexavalent chrome, diabetes, metabolic diseases
Volume II Issue 3 - 202I

\author{
Ahed J Alkhatib 1,2 \\ 'Department of Legal Medicine, Toxicology and Forensic \\ Medicine, Jordan University of Science \& Technology, Jordan \\ International Mariinskaya Academy, department of medicine and \\ critical care, department of philosophy, Academician secretary of \\ department of Sociology, Jordan
}

\author{
Correspondence: Ahed J Alkhatib, International Mariinskaya \\ Academy, department of medicine and critical care, department \\ of philosophy, Academician secretary of department of \\ Sociology, Jordan, Tel 00962795905 | 45, \\ Email ajalkhatib@just.edu.jo
}

Received: June 08, 202I | Published: June 21, 2021

\section{Introduction}

Since the discovery of the carcinogenic effects of hexavalent $\mathrm{Cr}$ at the end of the nineteenth century, chromium $(\mathrm{Cr})$ has been investigated. ${ }^{1}$ The essentiality of trivalent $\mathrm{Cr}$ was established in 1959; $\mathrm{Cr} 3+$ has been investigated in humans and laboratory animals since the 1970s, but $\mathrm{Cr}$ has only been investigated as an essential element in pastoral animals with the same intensity since the 1990 s. $^{2}$ Normal glucose, lipid, and protein metabolism all require trivalent chromium. ${ }^{3}$ Chromium is biologically active as part of an oligopeptide called chromodulin, which helps insulin attach to receptors on the cell surface, potentiating its impact. Because chromium is an insulin cofactor, $\mathrm{Cr}$ activity in the body is linked to insulin activities. ${ }^{4}$ Inorganic $\mathrm{Cr}$ absorption is modest, ranging between 0.4 and 2.0 percent, whereas organic $\mathrm{Cr}$ availability is more than 10 times higher. $\mathrm{Cr}$ that has been absorbed circulates in the circulation as part of the -globulin plasma fraction and is delivered to tissues that have been bound to transferrin. ${ }^{5}$ The demand for $\mathrm{Cr}$ has been rising as a result of stresses, particularly during various forms of dietary, metabolic, and physical strain. ${ }^{6}$

Diabetes mellitus (DM) is a metabolic condition in which diabetic patients have excessively high blood glucose levels due to inadequate insulin production or insulin resistance. ${ }^{7}$ In diabetic individuals, chronic hyperglycemia can harm different cells and organs, including the retina, heart, kidneys, and blood vessels. ${ }^{8}$ According to recent studies, the global prevalence of diabetes mellitus has risen from 451 million individuals in 2017 to 693 million people by $2045 .{ }^{9}$ Most individuals with increased blood glucose levels (more than 90\%) are diagnosed with type 2 diabetes (T2DM), which is insulin-independent pathologically. ${ }^{10}$

Increased blood glucose, fatty acid synthesis, and reactive oxygen and nitrogen species can all lead to mitochondrial and metabolic dysfunction, resulting in reduced insulin secretion by -cells. ${ }^{11}$ Furthermore, because free radicals play such an important part in the initiation and evolution of life, they are now referred to as "obligatory harmful chemicals." When free radicals cooperate with the superoxide dismutase enzyme, they can activate some signaling cascades, such as the extracellular signal regulated kinase (ERK) and/or mitogenactivated protein kinase (MAPK) pathways, which participate in the alteration of gene expression as well as the initiation of cell death. ${ }^{12}$

Free radical molecules are formed when oxygen reacts with nonenzymatic organic compounds, or they can be created by ionizing radiation. ${ }^{13}$ As a result, oxidative stress can be induced by a variety of factors, including cigarette smoking, reactive nitrogen species, reactive oxygen species (ROS), and irradiation. ${ }^{12}$ The decrease in the production of endogenous antioxidants such as superoxide dismutase (SOD), catalase (CAT, non-enzymatic/enzymatic), and glutathione peroxidase is primarily responsible for the elevated levels of ROS (GSH-Px). ${ }^{14}$ As a result, even if antioxidant enzyme levels are somewhat reduced, tissues and organs of the human body, such as the pancreas, are susceptible to oxidative stress. ${ }^{15}$ The mitochondrion is the principal source of oxidative stress in diabetes. Certain amounts of molecules are transformed into oxygen free radicals $(\mathrm{O} \bullet)$ during oxidative phosphorylation in mitochondria, which account for the majority of ROS. ${ }^{12}$ Other prooxidant agents, such as $\mathrm{OH}, \mathrm{H} 2 \mathrm{O} 2$, and ONOO, could be made from these molecules. ${ }^{15}$

Insulin signaling is precisely regulated by ROS/RNS via two routes, according to several lines of evidence. In addition, ROS/ RNS are generated in response to insulin signaling to complete their physiological activities. ${ }^{16,17}$ ROS and RNS have a negative feedback effect on the insulin signaling cascade, resulting in the development of insulin resistance, which is a risk factor for type 2 diabetes. ${ }^{18}$ Oxidative stress has also been linked to diabetes' micro- and macrovascular consequences, such as nephropathy and retinopathy. ${ }^{19}$ Inflammation and oxidative stress are hypothesized to have a causative relationship in renal and cardiovascular problems of diabetes. ${ }^{20}$ Medication, lifestyle changes, and complementary therapies such as vitamins, minerals, and herbal extracts are generally used to treat diabetes. ${ }^{21,22}$ Trivalent chromium is thought to be an insulin sensitizer that prevents 
the development of type 2 diabetes, according to prior research. The three stable forms of chromium found in nature are $0,3+$, and $6+$. 22 Chromium $3+$ appears to be beneficial for metabolic responses in the human body, ${ }^{23}$ but hexavalent chromium is harmful to people and animals. ${ }^{24}$

Chromium is abundant in whole grains, egg yolks, green beans, nuts, high-bran cereals, brewer's yeast, beef, beer, broccoli, and wine, but it is also present in small amounts in most fruits and vegetables, as well as dairy products. ${ }^{25}$ Chromium can enhance the number of insulin binding receptors and their phosphorylation rates, making glucose transfer into the liver, muscle, and adipose tissue easier. ${ }^{26}$

Additionally, chromium can increase the production of antioxidant enzymes and prevent lipid peroxidation via a variety of cellular mechanisms, including increased expression of the nuclear factor erythroid 2-related factor 2 (Nrf-2), ${ }^{27} 5$ '-adenosine monophosphateactivated protein kinase (AMPK) pathways ${ }^{28}$ and the inhibition and reduction of the MAPK pathway, all of which reduce oxidative stress. ${ }^{29}$ Furthermore, the antioxidant capabilities of chromium may help to reduce oxidative stress and inflammation produced by T2DM hyperglycemia. ${ }^{28}$

Another study found that dietary supplementation with chromium picolinate reduced the damage caused by oxidative stress in rats with induced diabetes, implying a potential positive effect on diabetic patients. ${ }^{30}$ Capsules with $200 \mathrm{~g}$ chromium picolinate are more prevalent in the United States, but the amount can be as high as 1000 $\mathrm{g}$, according to information gathered by MicromedexTM. ${ }^{31}$

Low $\mathrm{Cr}$ levels can influence blood glucose, insulin, total cholesterol, triglycerides, and high-density lipoprotein cholesterol, as $\mathrm{Cr}$ is essential for appropriate glucose and lipid. ${ }^{32,33}$ Although the minimum estimated safe and appropriate daily dietary intake for $\mathrm{Cr}$ for people aged 7 and up is 50-200 g/day, typical Western diets do not meet these needs. ${ }^{34}$ According to Anderson and Kozlovsky ${ }^{35}$ 90\% of the US population do not consume the recommended safe and appropriate daily dietary intake. According to a more recent study, adults in the United States consume less than the recommended daily intake of 25-35 $\mathrm{g}$ of $\mathrm{Cr}^{36}$ Brewer's yeast, beer, whole grains, cheese, liver, and pork are all good sources of $\mathrm{Cr}$ in the diet; however, the amount of $\mathrm{Cr}$ in different foods varies a lot. ${ }^{37}$ Furthermore, most of the absorbable $\mathrm{Cr}$ is removed during the refining of grains and sugars, as well as food preparation. ${ }^{38}$ Much of the $\mathrm{Cr}$ found in foods comes from contamination of food-processing equipment and is therefore not bioavailable. ${ }^{3}$

Reduced $\mathrm{Cr}$ status $^{39}$ and excessive ingestion of refined carbohydrates ${ }^{40}$ have both been linked to a higher prevalence of T2DM. Urinary Cr losses have been reported to increase 10-300\% after eating a high-sugar diet. ${ }^{38}$ Age, illness, pregnancy, burns, and stress can worsen relative $\mathrm{Cr}$ shortage. ${ }^{41}$ Hair analysis revealed low $\mathrm{Cr}$ status in more than half of 2,000 Canadian individuals in one epidemiological research. ${ }^{42}$

\section{Conclusions}

Chromium supplementation should be considered for potential use in controlling diabetes and metabolic disorders.

\section{Acknowledgments}

None.

\section{Conflicts of interest}

The authors declare that they have no conflict of interest.

\section{Funding}

None.

\section{References}

1. Cohen MD, Kargacin B, Klein CB, et al. Mechanisms of chromium carcinogenity and toxicity. Critical Reviews in Toxicology. 1993;23:255281.

2. Suzuki Y, Fukuda K. Reduction of hexavalent chromium by ascorbic acid and glutathione with special reference to the rat lung. Archives of Toxicology. 1990;64:169-176

3. Anderson RA, Kozlovsky AS. Chromium intake, absorption and excretion of subjects consuming self-selected diets. Am J Clin Nutr. 1985;41:11771183.

4. Vincent JB. The biochemistry of chromium. Journal of Nutrition 2000;130:715-718.

5. Sun YJ, Ramirez J, Woski SA, et al. The binding of trivalent chromium to low-molecular weight chromium-binding substance (LMWCr) and the transfer of chromium from transferrin and chromium picolinate to LMWCr. Journal of Biological Inorganic Chemistry. 2000;5:129-136.

6. Pechova A, Pavlata L. Chromium as an essential nutrient: a review. Veterinarni Medicina. 2007; 52 (1): 1-18.

7. Kooshki F, Moradi F, Karimi A, et al. Chromium picolinate balances the metabolic and clinical markers in nonalcoholic fatty liver disease. European Journal of Gastroenterology \& Hepatology. 2020.

8. Saracoğlu G, Baş H, Pandır D. Furan-induced cardiotoxicity in diabetic rats and protective role of lycopene. J Food Biochem. 2019;43(3):e12738

9. Nguekouo PT, Kuate D, Kengne APN, et al. Effect of boiling and roasting on the antidiabetic activity of Abelmoschus esculentus (Okra) fruits and seeds in type 2 diabetic rats. J Food Biochem. 2018;42(6):e12669.

10. Christensen MB, Gasbjerg LS, Heimbürger SM, et al. GIP's involvement in the pathophysiology of type 2 diabetes. Peptides. 2020;125:170178.

11. Fazelian S, Paknahad Z, Khajehali L, et al. The effects of supplementation with vitamin D on inflammatory biomarkers, omentin, and vaspin in women with type 2 diabetes: a randomized double-blind placebocontrolled clinical trial. J Food Biochem. 2018;42(6):e12631.

12. Asmat U, Abad K, Ismail K. Diabetes mellitus and oxidative stress-a concise review. Saudi Pharm J. 2016;24(5):547-553.

13. Singh R, Devi S, Gollen R. Role of free radical in atherosclerosis, diabetes and dyslipidaemia: larger-than-life. Diabetes Metab Res Rev. 2015;31(2):113-126.

14. Liu Z, Ren Z, Zhang J, et al. Role of ROS and nutritional antioxidants in human diseases. Front Physiol. 2018;9:477.

15. Gerber PA, Rutter GA. The role of oxidative stress and hypoxia in pancreatic beta-cell dysfunction in diabetes mellitus. Antioxid Redox Signal. 2017;26(10):501-518.

16. Ahmad W, Ijaz B, Shabbiri K, et al. Oxidative toxicity in diabetes and Alzheimer's disease: mechanisms behind ROS/RNS generation. J Biomed Sci. 2017;24(1):76.

17. Akbari A, Mobini GR, Agah S, et al. Coenzyme Q10 supplementation and oxidative stress parameters: a systematic review and meta-analysis of clinical trials. Eur J Clin Pharmacol. 2020;1-17. 
18. Bashan N, Kovsan J, Kachko I, et al. Positive and negative regulation of insulin signaling by reactive oxygen and nitrogen species. Physiol Rev. 2009;89(1):27-71.

19. Damavandi RD, Mousavi SN, Shidfar F, et al. Effects of daily consumption of cashews on oxidative stress and atherogenic indices in patients with type 2 diabetes: a randomized, controlled-feeding trial. Int J Endocrinol Metab. 2019;17(1):e70744.

20. Domingueti CP, Dusse LMS, Carvalho MDG, et al. Diabetes mellitus: the linkage between oxidative stress, inflammation, hypercoagulability and vascular complications. J Diabetes Complications. 2016;30(4):738-745.

21. Courcoulas AP, Gallagher JW, Neiberg RH, et al. Bariatric surgery vs lifestyle intervention for diabetes treatment: five year outcomes from a randomized trial. J Clin Endocrinol Metab. 2020;105(3):866-876.

22. Tutunchi H, Ostadrahimi A, Hosseinzadeh-Attar MJ, et al. A systematic review of the association of neuregulin 4, a brown fat-enriched secreted factor, with obesity and related metabolic disturbances. Obes Rev. 2020;21(2):e12952.

23. Farrokhian A, Mahmoodian M, Bahmani F, et al. The influences of chromium supplementation on metabolic status in patients with type $2 \mathrm{c}$ and coronary heart disease. Biol Trace Elem Res. 2020;194(2):313-320.

24. Husain N, Mahmood R. Hexavalent chromium induces reactive oxygen species and impairs the antioxidant power of human erythrocytes and lymphocytes: Decreased metal reducing and free radical quenching ability of the cells. Toxicol Ind Health. 2017;33(8):623-635.

25. Kooshki F, Niazkar HR, Shirazi S, et al. Fumaria parviflora improves liver damage and lipid profile changes in STZ-induced diabetic rats. Physiol Pharmacol. 2020;24(3):221-229.

26. Lipko M, Debski B. Mechanism of insulin-like effect of chromium (III) ions on glucose uptake in $\mathrm{C} 2 \mathrm{C} 12$ mouse myotubes involves ROS formation. J Trace Elem Med Biol. 2018;45:171-175.

27. Kim J, Chung K, Johnson BJ. Chromium acetate stimulates adipogenesis through regulation of gene expression and phosphorylation of AMPK in bovine intramuscular or subcutaneous adipocytes. Asian-Australas $J$ Anim Sci. 2019;33(4):651-661.

28. Lukaski HC. Effects of chromium (III) as a nutritional supplement In: Vincent J, editor. The Nutritional Biochemistry of Chromium (III). Cambridge, MA: Elsevier. 2019;61-77.

29. Feng W, Ding Y, Zhang W, et al. Chromium malate alleviates highglucose and insulin resistance in L6 skeletal muscle cells by regulating glucose uptake and insulin sensitivity signaling pathways. Biometals. 2018;31(5):891-908.
30. Sundaram B, Aggarwal A, Sandhir R. Chromium picolinate attenuates hyperglycemia-induced oxidative stress in streptozotocin-induced diabetic rats. J Trace Elem Med Biol. 2013;27(2):117-121.

31. Gisele Mara Silva Gonçalves, Pedro Paulo Barros, Gustavo Henrique da Silva, Júlia Ferreira Watanabe, et al. Influence of silymarin and chromium picolinate on the pharmacotherapy of rats with induced diabetes. Rev Colomb Cienc Quím Farm. 2020;49(1):5-16.

32. Cefalu WT, Hu FB. Role of chromium in human health and in diabetes. Diabetes Care. 2004;27:2741-2751.

33. Wang H, Kruszewski A, Brautigan DL. Cellular chromium enhances activation of insulin receptor kinase. Biochemistry. 2005;44:8167-8175.

34. Leigh Broadhurst C, Philip Domenico. Clinical Studies on Chromium Picolinate Supplementation in Diabetes Mellitus-A Review. Diabetes Technology \& Therapeutics. 2006;8(6).

35. Anderson RA, Bryden NA, Polansky MM, et al. Dietary chromium effects on tissue chromium concentrations and chromium absorption in rats. Journal of Trace Elements in Experimental Medicine. 1996;9:11-25.

36. Juturu V, Komorowski JR. Consumption of selected food sources of chromium in the diets of American adults [abstract]. FASEB J. 2003;17:A1129.

37. Offenbacher EG, Pi-Sunyer FX, Stoecker BJ. Chromium. In: O’Dell BL, Sunde RA, eds. Handbook of Nutritionally Essential Mineral Elements. New York: Marcel Dekker, 1997:389-411.

38. Kozlovsky AS, Moser PB, Reiser S, et al. Effects of diets high in simple sugars on urinary chromium losses. Metabolism. 1986;35:515-518.

39. Rajpathak S, Rimm E B, Li T, et al. Lower toenail chromium in men with diabetes and cardiovascular disease compared with healthy men. Diabetes Care. 2004;27:2211-2216.

40. Gross LS, Li L, Ford ES, et al. Increased consumption of refined carbohydrates and the epidemic of type 2 diabetes in the United States: an ecologic assessment. Am J Clin Nutr. 2004;79:774-779.

41. Campbell WW, Joseph LJ, Davey SL, et al. Effects of resistance training and chromium picolinate on body composition and skeletal muscle in older men. J Appl Physiol. 1999;86:29-39.

42. Campbell JD. Lifestyle, minerals and health. Med Hypotheses. 2001;57:521-531. 